\title{
Rancang Bangun Sistem Monitoring Ruang Kelas Berbasis Internet of Things pada Universitas Pamulang
}

\author{
Joko Riyanto ${ }^{1}$, Farida Nurlaila ${ }^{2}$, Heri Haerudin ${ }^{3}$, Bayu Tirto Jarastino $^{4}$ \\ Teknik Informatika, Universitas Pamulang, Jl. Raya Puspitek No.46, Buaran, Serpong Tangerang \\ Selatan, Banten, Indonesia, 15310 \\ e-mail: 1 jokoriyanto@unpam.ac.id, ${ }^{2}$ faridanurlaila09@ gmail.com, ${ }^{3}$ reheri2709@gmail.com, \\ ${ }^{4}$ bang.bayutirto@gmail.com
}

Submitted Date: September $19^{\text {th }}, 2020$

Revised Date: December $31^{\text {st }}, 2020$

\author{
Reviewed Date: December 30 3020 \\ Accepted Date: January $04^{\text {th }}, 2021$
}

\begin{abstract}
In a classroom, ideally there are facilities such as chairs, desks, blackboards, and electronic devices used such as air conditioners (AC), lamps and projectors. However, in its use, there are actions that are not responsible for maintaining the facility so that it causes losses. An internet of things-based classroom monitoring system is needed to solve existing problems. This system has the ability to remotely operate electronic facilities in classrooms such as air conditioning, electricity and lights, monitor access to classrooms, process data, print activity monitoring reports, to monitor the current conditions of a room. This system consists of three parts, namely the database part, the microcontroller section and the software section. The database section contains data on access cards or fingerprints, room usage schedules, room temperature and humidity. The methodology for designing and building a classroom monitoring system uses the waterfall methodology. In this methodology, several steps are taken to build a system, namely: system requirements analysis, hardware design and software engineering, system design, system implementation, system testing, and system maintenance. Based on the test results, this system can record input data on the microcontroller section and display it in the software section for real-time monitoring and controlling of classrooms and minimizing damage to existing facilities in the classroom. Monitoring of classroom use that is not according to the schedule of use can be carried out and controlled remotely in real-time.
\end{abstract}

Keywords: Monitoring; Smart Class; Internet of Things.

\begin{abstract}
Abstrak
Dalam sebuah ruang kelas, idealnya terdapat fasilitas seperti kursi, meja, papan tulis, dan perangkat elektronik yang digunakan seperti Air Conditioner (AC), lampu dan proyektor. Namun dalam penggunaannya terdapat tindakan yang tidak bertanggungjawab dalam menjaga fasilitas tersebut hingga menimbulkan kerugian. Sistem monitoring ruang kelas berbasis internet of things sangat dibutuhkan untuk mengatasi permasalahan yang ada. Sistem ini memiliki kemampuan dalam mengoperasikan fasilitas elektronik dalam ruang kelas dari jarak jauh secara realtime seperti $A C$, listrik, dan lampu, memantau akses masuk ruang kelas, mengolah data, mencetak laporan monitoring kegiatan, hingga memantau kondisi terkini dari suatu ruangan. Sistem ini terdiri dari tiga bagian, yaitu bagian basis data, bagian microcontroller dan bagian perangkat lunak. Bagian basis data berisi data-data kartu akses masuk atau sidik jari, jadwal penggunaan ruangan, suhu dan kelembapan ruangan. Metodologi perancangan dan pembangunan sistem monitoring ruang kelas ini menggunakan metodologi waterfall. Dalam metodologi ini dilakukan beberapa langkah untuk membangun sebuah sistem, yaitu: analisa kebutuhan sistem, perancangan perangkat keras dan rekayasa perangkat lunak, perancangan sistem, implementasi sistem, pengujian sistem, dan pemeliharaan sistem. Berdasarkan hasil pengujian sistem ini dapat merekam input data pada bagian microcontroller dan ditampilkan pada bagian perangkat lunak untuk monitoring dan mengendalikan ruang kelas secara real-time dan meminimalisir kerusakan fasilitas yang ada di dalam ruang kelas. Monitoring
\end{abstract}


pemakaian ruang kelas yang tidak sesuai jadwal penggunaan dapat dilakukan dan dikendalikan dari jarak jauh secara real-time.

Kata Kunci : Monitoring; Ruang Kelas; Internet of Things.

\section{Pendahuluan}

Pesatnya perkembangan dan kemajuan ilmu pengetahuan saat ini membuat zaman memasuki era baru dimana teknologi sangat berpengaruh pada kehidupan kita salah satunya adalah penggunaan teknologi seperti Internet of Things (IoT). Dengan adanya koneksi internet, setiap objek yang terhubung dengan komputer dapat bekerja sesuai aktivitas yang direncanakan dari masing-masing perangkat yang digunakan (Sulenggono \& Wibawa, 2017). Melihat perkembangan seperti diatas, seharusnya lembaga pendidikan mulai berinovasi dengan mengadopsi sistem cerdas untuk meningkatkan kualitas pembelajaran.

Universitas Pamulang merupakan sebuah perguruan tinggi swasta yang saat ini semakin maju dan membutuhkan sebuah sistem yang dapat meningkatkan kinerja proses pembelajaran. Saat ini di Universitas Pamulang masih mengandalkan tenaga manusia untuk membuka ruang kelas, menyalakan atau mematikan fasilitas elektronik di dalamnya seperti Air Conditioner (AC), lampu dan proyektor. Faktor kelalaian manusia dapat terjadi dengan adanya ruang kelas yang selesai digunakan, namun aliran listrik dan fasilitas lampu maupun AC masih menyala, sehingga menyebabkan pemakaian listrik terbuang percuma dan beban pemakaian daya listrik pun ikut bertambah (Masykur, Fauzan, \& Prasetiyowati, 2016).

Berdasarkan pada ide pemanfaatan teknologi untuk sebuah ruang kelas, pada penelitian ini akan dibuat sistem monitoring ruang kelas yang merupakan gabungan sistem dari perangkat keras berupa mikrokontroller dan perangkat lunak berupa aplikasi cerdas yang dipasang pada ruang kelas yang nantinya dapat mengendalikan pengoperasian alat elektronik dan pemantauan kondisi ruang kelas saat proses perkuliahan sedang berlangsung.

Konsep sistem monitoring yang telah berkembang saat ini akan digunakan sebagai pendukung perancangan sistem monitoring ruang kelas dengan menggabungkan teknologi IoT (Internet of things) untuk meningkatkan kinerja pembelajaran dalam bidang akademik (Prihatmoko, 2016). Sistem monitoring tidak hanya berfokus pada aspek peningkatan kinerja pembelajaran namun juga pada aspek keamanan
(Saleh \& Haryanti, 2017), sebuah ruangan dengan menggunakan RFID atau Fingerprint sebagai syarat untuk mengakses ruang kelas, dan juga aspek penghematan sumber daya listrik akibat fasilitas elektronik yang terus aktif pada ruang kelas sedangkan tidak adanya aktivitas belajar mengajar pada ruangan tersebut, maka akan dibuat sistem monitoring untuk memantau aktivitas akses ruang kelas dan perangkat elektronik di dalamnya.

Sistem monitoring melalui interface berupa web application ini menggunakan hardware pendukung berupa Raspberry Pi sebagai client device atau perangkat untuk membantu dalam mengolah data yang diambil dari database sehingga sistem monitoring dapat memantau segala aktivitas secara realtime. Raspberry $\mathrm{Pi}$ dapat digunakan untuk menunjang sistem secara realtime untuk mencapai tujuan dengan hanya menggunakan mikrokontroller (Al-Qorni, Azhar, \& Yuniarti, 2018).

\section{Landasan Teori}

\subsection{Rancang Bangun}

Rancang bangun merupakan sebuah cara untuk menciptakan sebuah sistem baru yang mampu menggantikan atau memperbaiki sistem sebelumnya baik secara keseluruhan atau sebagian (Hartono, 2013). Rancang bangun dalam sistem adalah upaya menerjemahkan hasil analisa ke dalam bentuk paket perangkat lunak kemudian menciptakan sistem tersebut.

\subsection{Teori Sistem}

Sistem merupakan suatu komponen yang saling terhubung untuk menciptakan sebuah interaksi guna mencapai suatu tujuan. Sistem yang besar biasanya terdiri dari sistem kecil yang saling mendukung satu sama lain (Romney \& Steinbart, 2015).

\subsection{Teori Monitoring}

Monitoring didefinisikan sebagai cara mengkaji suatu kegiatan apakah berjalan sesuai yang direncanakan, adakah masalah yang ditimbulkan atau cara kerja yang sudah sesuai pola yang ditentukan. Jika terdapat masalah yang timbul dapat segera diatasi, tujuannya untuk memperoleh kemajuan (Sutabri, 2016).

\subsection{Teori Internet of Things}


Internet of Things merupakan layanan informasi berupa infrastruktur global yang saling menghubungkan benda fisik dan virtual sesuai dengan teknologi yang dimiliki berdasarkan perkembangannya. Definisi lain Internet of Things adalah benda-benda teknologi berupa perangkat fisik yang saling bertukar informasi satu sama lain. Infrastruktur IoT berupa perangkat keras elektronik, perangkat lunak, sensor dan juga terdapat konektivitas. Perangkat fisik ini saling beroperasi dalam suatu jaringan infrastruktur seperti internet (Stallings, 2015).

\section{Metodologi Penelitian}

Dalam penelitian ini metode yang digunakan penulis adalah mulai dari tahap penyusunan rumusan masalah sehingga membentuk alur yang sistematis. Metode ini dijadikan pedoman penulisan guna mencapai hasil yang diinginkan dan tidak menyimpang dari pokok permasalahan yang dibahas. Adapun beberapa metode penelitian lainnya yang digunakan yaitu:

\section{a. Studi Pustaka}

Metode studi pustaka digunakan untuk mengumpulkan informasi berupa literatur seperti jurnal, buku, dan datasheet. Adapun informasi dikumpulkan dari berbagai sumber lain seperti video, dan artikel dari internet. Informasi datasheet yang dikumpulkan berupa datasheet Raspberry Pi, Bahasa pemrograman Python, bahasa pemrograman PHP, module RFID Mifare RC522, module fingerprint, module DHT22, module light dependent resistor (LDR), dan datasheet Waveshare HDMI 5 inch $L C D(B)$.

\section{b. Studi Literatur}

Metode studi literatur digunakan untuk mencari artikel jurnal atau buku yang berkaitan dengan penelitian. Hasil studi literatur dijadikan sebagai sumber informasi dan landasan dalam penelitian sehingga tidak terjadi penyimpangan teori.

\section{c. Perancangan dan Pembuatan Alat}

Metode perancangan dan pembuatan alat dimulai dari penyusunan perangkat keras. Rangkaian elektronik yang digunakan dihubungkan pada port-port GPIO yang terdapat pada raspberry pi, dan penyusunan selanjutnya berupa sistem yang dapat mengelolah data pada raspberry pi seperti pembuatan aplikasi antar muka. Diagram blok sistem pada penyusunan perangkat keras dan lunak dapat dilihat pada Gambar 1.

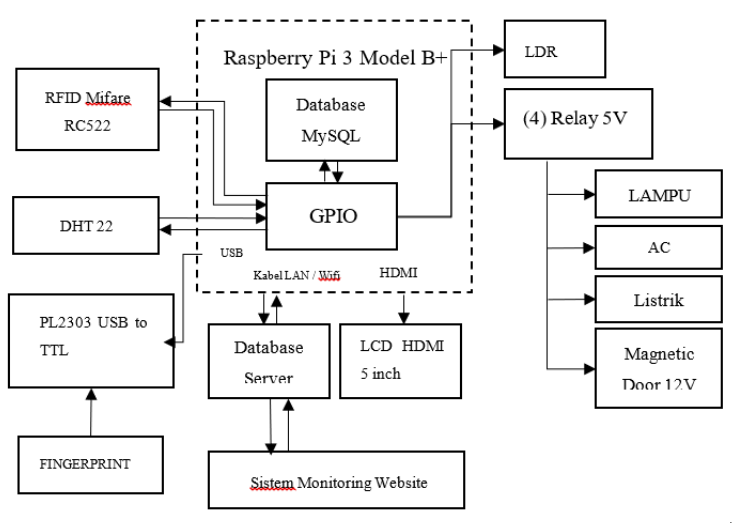

Gambar 1 Diagram Blok Sistem

\section{d. Pengujian dan Pengambilan Data}

Metode pengujian dan pengambilan data digunakan untuk menguji dan mengkaji apakah sistem berjalan sesuai yang direncanakan. Pengujian pada setiap komponen untuk memastikan apakah berfungsi sesuai yang diharapkan.

\section{e. Metodologi Waterfall}

Metodologi waterfall digunakan sebagai alur untuk membangun sebuah perangkat lunak dimulai dari tahap analisa kebutuhan sistem, tahan desain atau perancangan sistem, tahap implementasi sistem, tahap pengujian sistem dan yang terakhir adalah tahap pemeliharaan sistem. Setelah semua langkah berhasil dilakukan maka terbentuklah sebuah sistem yang sesuai dengan kebutuhan (Sukamto \& Salahuddin, 2014).

\section{Analisis dan Implementasi 4.1 Analisis Sistem Berjalan}

Analisa sistem berjalan dimulai dari penulis menganalisa cara kerja sistem dan pihak yang melaksanakan dan segala sesuatu yang berhubungan dengan sistem bertujuan untuk mengetahui kelemahan pada sistem tersebut. Membuat sebuah sistem baru penulis membuat analisa berdasarkan penelitian yang didapat dari sana adalah tidak adanya otomatisasi dalam menggunakan ruangan dan alat elektronik didalam ruangan sehingga penulis membuat solusi yaitu berupa sistem monitoring ruang kelas untuk mempermudah dosen, mahasiswa maupun staff Universitas Pamulang dalam menggunakan fasilitas ruangan tersebut. Analisa prosedur berjalan yang diuraikan berdasarkan aktivitasaktivitas penggunaan sistem ruang kelas secara sistematis adalah sebagai berikut: 

a. Dosen memasuki ruangan
b. Mahasiswa memasuki ruangan
c. Petugas menyalakan listrik
d. Petugas menyalakan lampu
e. Petugas menyalakan AC
f. Dosen keluar dari ruangan
g. Mahasiswa keluar dari ruangan
h. Petugas mematikan AC
i. Petugas mematikan lampu
j. Petugas mematikan listrik

Pada prosedur sistem berjalan diatas, proses persiapan ruang kelas belum dilakukan secara komputerisasi. Berikut ini merupakan activity diagram sistem berjalan:

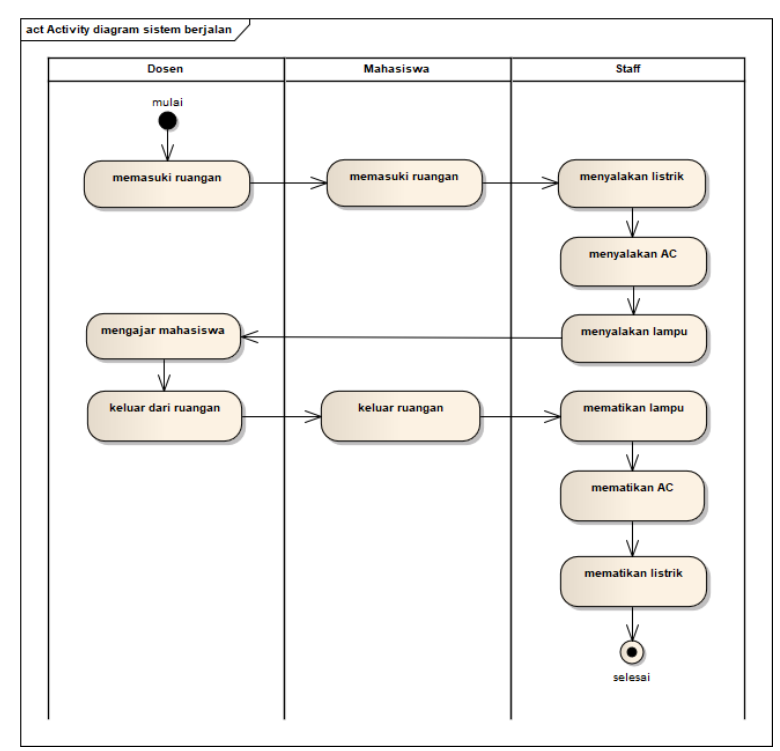

Gambar 2 Activity Diagram Sistem Berjalan

\subsection{Analisis Sistem Usulan}

Pada sistem yang diusulkan ini terdapat tiga pengguna sistem, yaitu: user Admin yang memiliki seluruh hak akses pada sistem ini. Yang kedua adalah user Dosen yang memiliki hak akses pada sistem ini antara lain untuk menyalakan AC, listrik dan pintu otomatis serta menampilkan nama user pada tampilan LCD. Yang ketiga adalah user Mahasiswa yang memiliki hak akses pada sistem ini antara lain untuk menyalakan listrik pada ruangan tersebut. dari:

Proses sistem yang akan diusulkan terdiri

a. Proses mengidentifikasi tag RFID atau sidik jari. Sistem akan mengidentifikasi tag/kartu tanda identitas user atau sidik jari dan melakukan validasi untuk penggunaan pada ruangan tersebut. b. Proses melakukan pemantauan dan pengendalian pada alat elektronik ruangan

c.Proses kendali lampu otomatis

d. Proses membaca suhu dan kelembapan dalam ruangan

e. Proses pendaftaran user dosen dan mahasiswa. Pada proses ini user mendaftarkan diri ke admin, admin menggunakan sistem untuk mengidentifikasi tag/kartu tanda identitas dan sidik jari, admin mendaftarkan tag/kartu tanda identitas dan sidik jari yang telah diidentifikasi melalui sistem monitoring website.

\subsection{Implementasi}

Implementasi rangkaian perangkat keras yang telah dihasilkan dari perancangan yang telah dilakukan pada sistem monitoring ruang kelas. Dibawah ini adalah beberpa tampilan dari prototype yang dihasilkan:

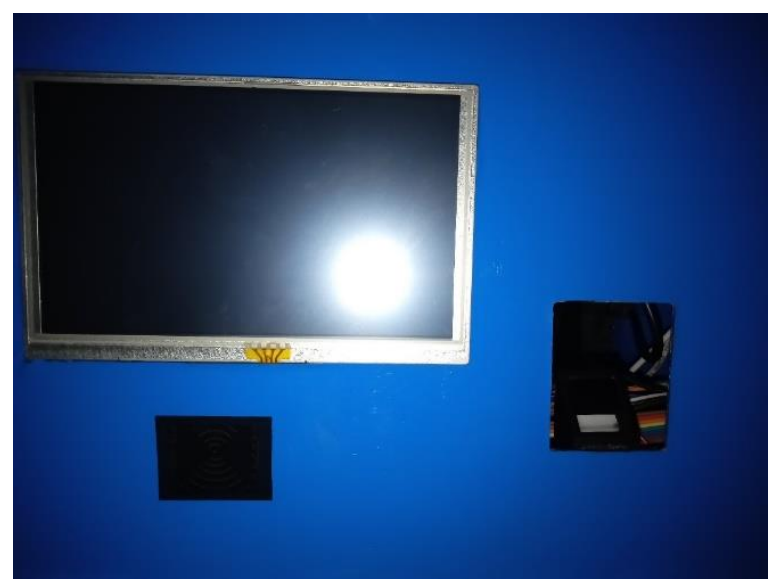

Gambar 3 Implementasi Prototype

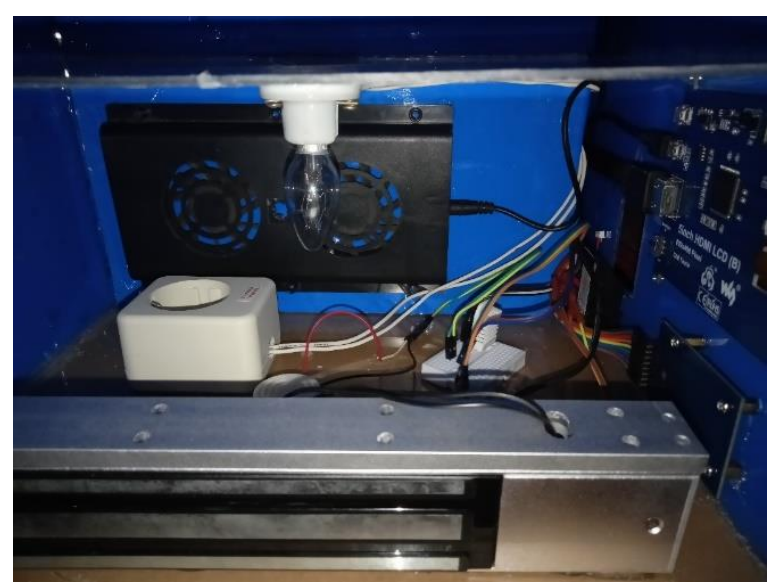

Gambar 4 Implementasi Prototype 


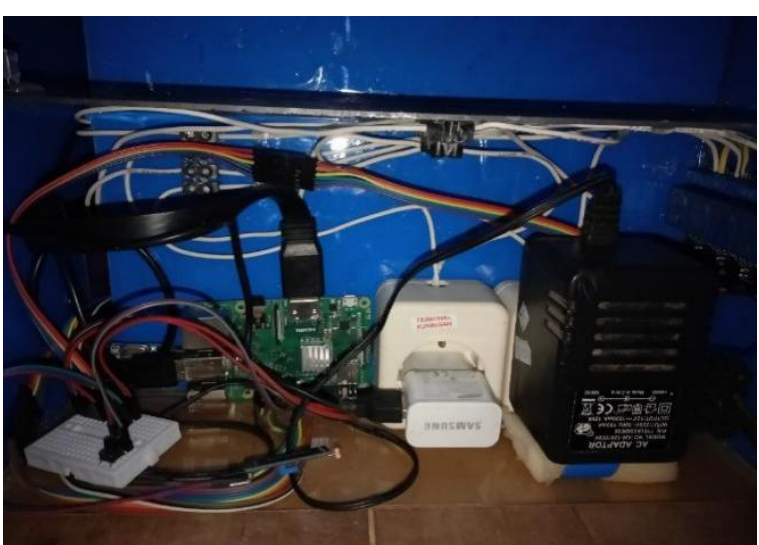

Gambar 5 Implementasi Prototype

\section{a. Tampilan Halaman Home}

Tampilan halaman home merupakan halaman pertama yang tampil saat pertama kali menjalankan sistem. Tampilan ini memiliki fungsi untuk menampilkan nomor ruang, waktu, keadaan suhu dan humidity pada ruangan dan mengubah label apabila mendapatkan trigger dari tag user Admin.



Gambar 6 Tampilan Halaman Home

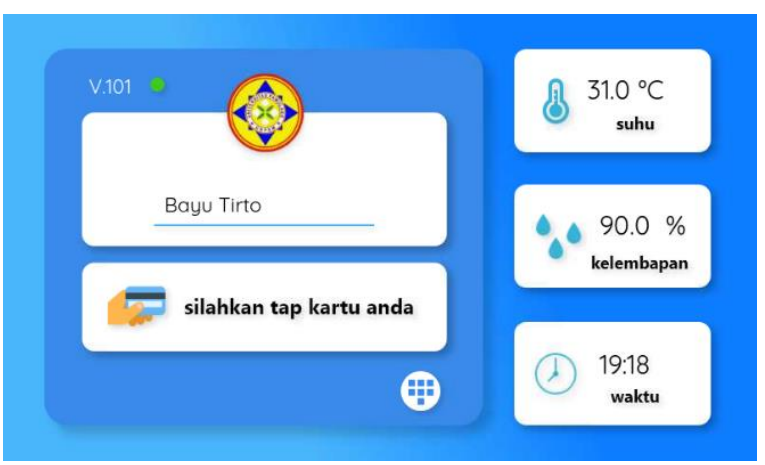

Gambar 7 Tampilan Halaman Home

b. Tampilan Halaman Akses Pin
Tampilan halaman akses pin merupakan tampilan untuk memasukan pin sesuai dengan kode akses ruangan pada sistem tersebut. Tampilan ini memiliki fungsi akses tanpa kartu.

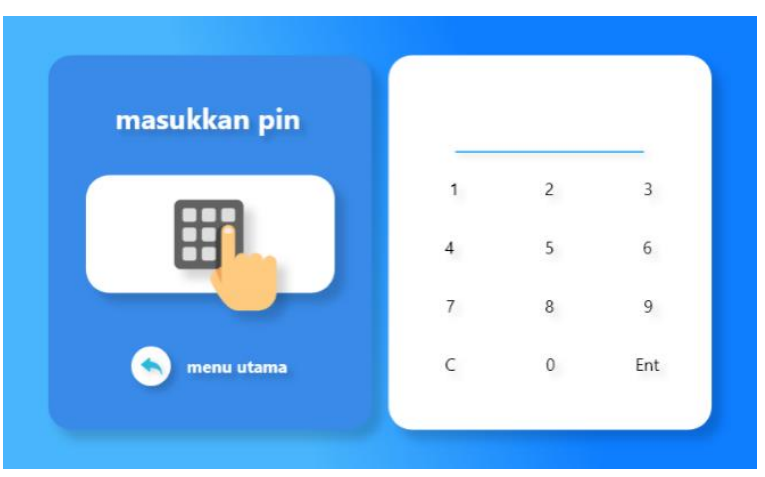

Gambar 8 Tampilan Menu Akses Pin

c. Tampilan Alert Akses Berhasil

Tampilan ini akan muncul apabila data yang diterima oleh RFID.Tampilan ini memiliki fungsi untuk informasi pada Halaman PIN adalah valid dan data terdapat pada sistem.

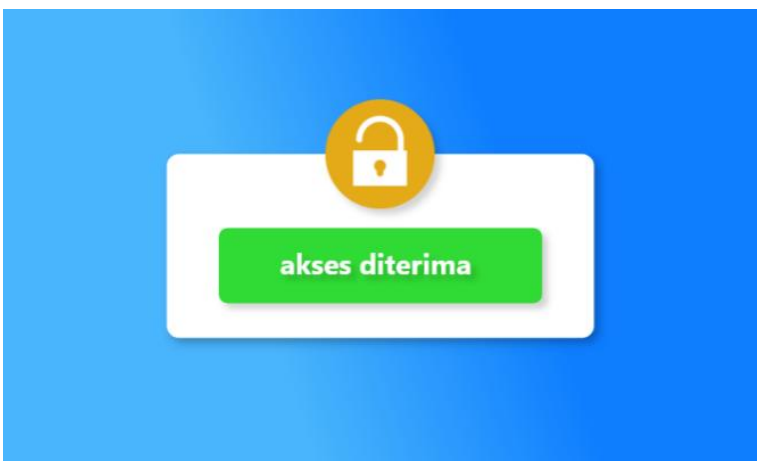

Gambar 9 Tampilan Alert Akses Berhasil

\section{d. Tampilan Alert Akses Gagal}

Tampilan ini akan muncul apabila data yang diterima oleh RFID. Tampilan ini memiliki fungsi untuk informasi pada Halaman PIN adalah invalid dan data tidak terdapat pada sistem. 


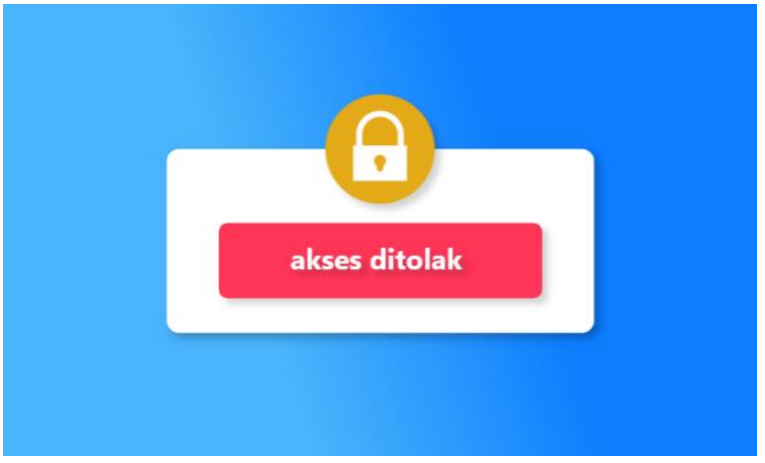

Gambar 10 Tampilan Alert Akses Gagal

\section{e Tampilan Login Monitoring Website}

Halaman login merupakan tampilan pertama saat website pertama kali dijalankan oleh admin sistem monitoring ruangan. Halaman login ini memiliki fungsi untuk masuk ke dalam sistem.

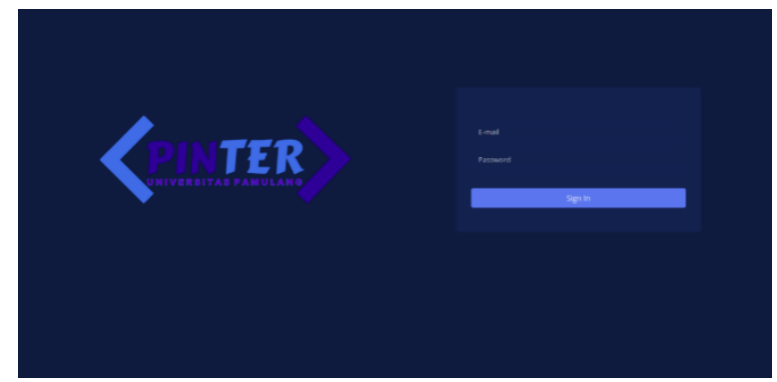

Gambar 11 Tampilan Login Monitoring Website

\section{f Tampilan Dashboard Monitoring Website}

Halaman dashboard merupakan tampilan setelah admin melakukan login ke dalam sistem. Halaman dashboard berfungsi sebagai shortcut untuk melihat semua aktivitas yang berhubungan dengan data.

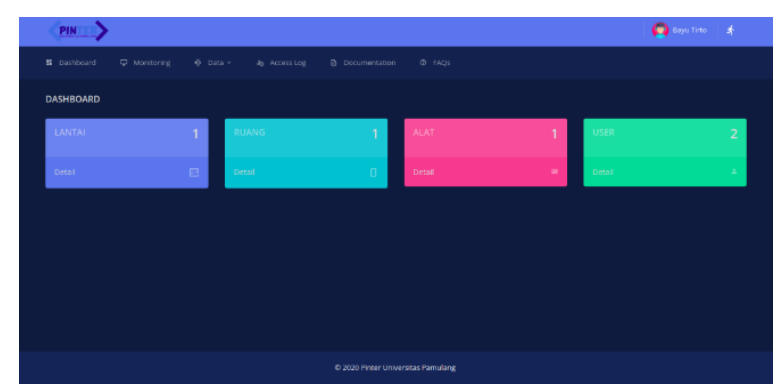

Gambar 12 Tampilan Dashboard Monitoring Website

\section{g Tampilan Halaman Monitoring}

Halaman Monitoring berisi informasi tentang lantai, ruangan, alat, suhu dalam satu table.
Tujuannya agar admin dapat mengetahui situasi seluruh ruangan dalam satu waktu.

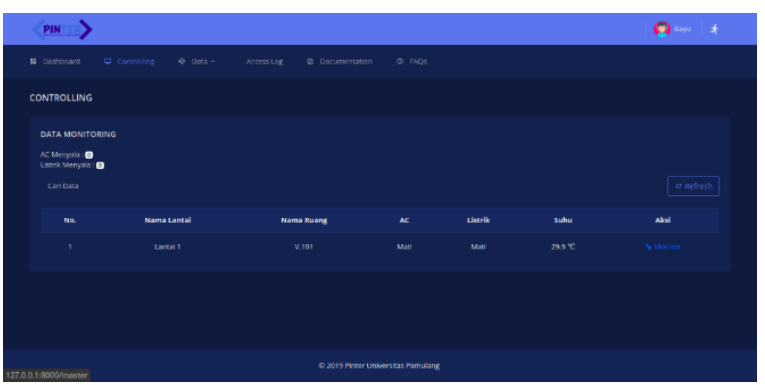

Gambar 13 Tampilan Halaman Monitoring

\section{h Tampilan Halaman Controlling}

Halaman controlling adalah halaman di mana admin bisa melakukan kontrol terhadap sebuah ruangan. Admin dapat menghidupkan atau mematikan perangkat dalam ruangan.

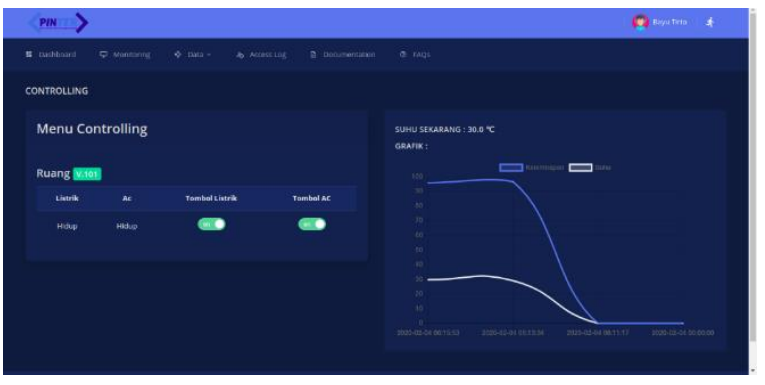

Gambar 14 Tampilan Halaman Controlling

\section{i Tampilan Menu Data}

Tampilan menu data merupakan halaman yang digunakan oleh admin untuk melihat data, admin juga bisa untuk melakukan fungsi ubah, tambah, dan hapus terhadap data.



Gambar 15 Tampilan Menu Data

\section{j Tampilan Halaman Log Akses}

Halaman log akses berfungsi untuk menampilkan data user yang mengakses suatu ruangan dalam satu waktu. Petugas dengan mudah 
mengetahui akses keluar masuk ruangan secara real-time.

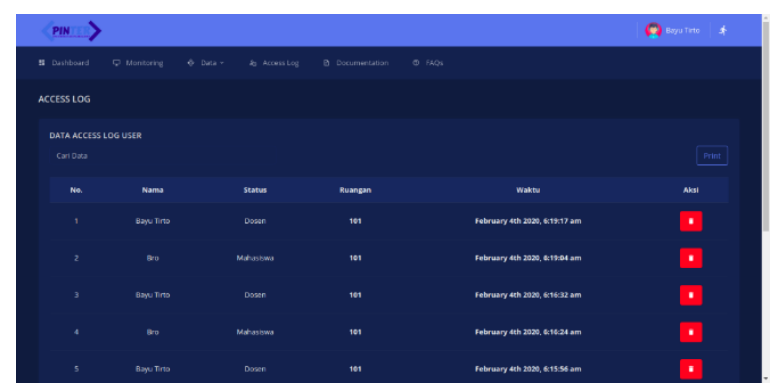

Gambar 16 Tampilan Menu Log Akses

\section{Kesimpulan}

Berdasarkan hasil analisa, perancangan, implementasi dan pengujian sistem monitoring ruang kelas berbasis internet of things pada Universitas Pamulang maka dapat diambil kesimpulan yaitu:

a. Mempermudah dalam melakukan pemantauan akses masuk ruang kelas berdasarkan status user dan penggunaan fasilitas dalam ruang kelas.

b. Mempermudah pemantauan dan pengendalian alat elektronik dari jarak jauh secara realtime.

c. Mempermudah dalam memantau kondisi dalam penggunaan ruang kelas dengan adanya informasi berupa temperature dan aktivitas penggunaan ruang kelas saat sedang digunakan untuk kegiatan belajar mengajar ataupun tidak.

\section{Referensi}

Al-Qorni, W., Azhar, A., \& Yuniarti, E. (2018). Perancangan Sistem Kontrol Otomatis Berbasis Web Menggunakan Raspberry Pi 3 pada Smarthome. AL-FIZIYA.

Hartono, B. (2013). Sistem Informasi Manajemen Berbasis Komputer. Jakarta: Rineka Cipta.

Masykur, Fauzan, \& Prasetiyowati, F. (2016). Aplikasi Rumah Pintar (Smart Home) Pengendali Peralatan Elektronik Rumah Tangga Berbasis Web. Jurnal Sains, Teknologi dan Industri, 93-100.

Prihatmoko, D. (2016). Penerapan internet of things (iot) dalam pembelajaran di unisnu jepara. SIMETRIS, 567-574.

Romney, M. B., \& Steinbart, P. J. (2015). Accounting Information System. England: Personal Educational Limited.
Saleh, M., \& Haryanti, M. (2017). Rancang Bangin Sistem Keamanan Rumah Menggunakan Relay. Jurnal Teknologi Elektro, 87-94.

Stallings, W. (2015). Foundation of modern networking SDN, NFV, QoE, iot, and Cloud. United States: Pearson Education.

Sukamto, R. A., \& Salahuddin, M. (2014). Rekayasa Perangkat Lunak. Bandung: Informatika.

Sulenggono, R., \& Wibawa, S. C. (2017). Penerapan Sistem Informasi Smart Classroom Berbasis Internet Of Things dengan Raspberry Pi di Jurusan Teknik Informatika Universitas Negeri Surabaya. Jurnal IT-EDU, 256-262.

Sutabri, T. (2016). Sistem Informasi Manajemen. Yogyakarta: Andi Offset. 